Hua Song, Lan Wang

\title{
Does Inter-Firm Learning and Trust Promote Firm Innovativeness?
}

\author{
(C) Higher Education Press and Springer-Verlag 2010
}

\begin{abstract}
This paper elaborates on a theoretical framework that assesses the effects of inter-firm trust and learning on firm's subsequent innovation output. We argue that joint problem solving arrangements play an intermediate role in firm innovativeness by promoting the sharing of complex and difficult-to-codify knowledge and information. Using survey data from a sample of 194 firms from the mainland of China, we find that inter-firm trust and learning have positive impacts on both buyer innovativeness and seller innovativeness. It is also found that there is a positive interactive relationship between trust and learning. Furthermore, their inter-effect and complementarity facilitate innovativeness by promoting joint problem solving at the firm level. Based on these findings, theoretical and managerial implications are discussed.
\end{abstract}

Keywords inter-firm learning, trust, joint problem solving, innovation performance

\section{Introduction}

Alliance and partner-like relationship have become increasingly popular across a broad span of firms and industries in a globalized and networked economy. Alliances promote innovations by providing access to a diverse variety of

Translated from Kexиexue yu Kexue Jishu Guanli 科学学与科学技术管理 (Science of Science and Management of S.\&T.), 2009, (4): 159-166

Hua Song $(\bowtie)$

School of Business, Renmin University of China, Beijing 100872, China

E-mail: songhua@ruc.edu.cn

Lan Wang

School of International Business, Beijing Language and Culture University, Beijing 100083, China

E-mail: im2003@163.com 
capabilities and expertise (Stuart, 1998; Ahuja, 2000). Scholars and practitioners are increasingly interested in exploring why some alliances "out-innovate" others. The issue of how collaborative behavior can create innovation performance has become a fundamental research issue.

Although learning and trust are frequently assumed as central to the acquisition of innovative capabilities through inter-firm ties (Ahuja, 2000; Gulati, 1999; Stuart, 1998), the effects of learning and trust are typically inferred rather than examined directly. Previously studies have explored how different elements of inter-firm ties affect innovation performance. However, the process in which different resources are combined and codified knowledge is transferred into innovative capability remains unclear. To address this issue, this study examines a relatively under-explored tension in the literature, i.e. the path and mechanism of the inter-firm ties influencing innovation performance from both buyer and seller perspectives.

\section{Theoretical Background and Hypotheses}

It has long been argued that inter-firm network relationships play an important role in new product innovation (e.g., Gulati, 1999; Marshall, 2004; Ragatz, Handfield and Scannel, 1997), because of their facilitative role in various inter-firm contexts (Teece, 1989). Network relationships can offer relational resources that enable firms to leverage and exploit other types of resources, to achieve better innovation performance (Granovetter, 1985; Shane and Cable, 2002). Informational advantages are one form of network resources that have received considerable attention. More specifically, by participating in inter-firm networks, a firm can gain access to not only heterogeneous of capabilities and knowledge provided by interactive learning, but also reliable advice and recommendations of an exchange partner for inter-firm trust (McEvily and Marcus, 2005).

Previous research on assessing the effects of a firm's network of relations on innovation has mainly focused on knowledge creation and adoption or diffusion of innovations. More recently, however, a few pioneering studies have explored network ties types from the perspective of innovation generation (Ahuja, 2000; Podolny and Stuart, 1995; Powell, Koput, and Smith-Doerr, 1996; Tiwana, 2008). For instance, Ahuja (2000) explored the role of direct ties, indirect ties, and structural holes (disconnections between a firm's partners) to the firm's subsequent innovation output. They found that both direct and indirect ties positively affect innovation. Yet the impact of indirect ties is moderated by the number of direct ties a firm has. Structural holes are proposed to have both positive and negative influences on subsequent innovation. Tiwana (2008) suggested that strong ties complement bridging ties in enhancing alliance 
ambidexterity at the project level. Nevertheless, they did not directly examine the content or essence of the inter-firm network ties as a predictor of innovation output. This narrow focus limits theoretical completeness and is a significant gap in the literature. Direct and indirect ties may vary in their magnitude and content highlights the importance of decomposing the buyer and seller relationship into distinct and separate elements and identifying the contents transmitted through each type of tie (McEvily and Marcus, 2005).

More importantly, what has not been systematically investigated is the mechanism of how relational recourses facilitate innovation. Since the knowledge underlying innovative capabilities is partially tacit, it is difficult to articulate and transfer, in other words, we claim that the effects of learning and trust typically are inferred rather than examined directly (Uzzi, 1997). In particular, we focus on the role of joint problem solving as the mechanism in the joint value creation process and investigate the extent to which joint problem solving between buyer and supplier firms mediates the links among key antecedents and outcome variables within a coherent theoretical framework. Such an investigation is needed in order to advance theory building and empirical testing in supply chain management. By viewing inter-organizational joint problem solving as a relational competency and empirically investigating its mediating role between tie characteristics and innovative performance, especially from both buyer and seller perspective, we seek to gain a better and integrative understanding of the strategic importance of this construct within the context of buyer-supplier relationships. To date, however, little theoretical or empirical work has addressed this issue.

In this study, we aim to address the above gaps in the literature by examining the roles and mechanism of trust and learning on firm innovation performance in the buyer-seller relationship context. Inter-organization trust is defined as the extent of the willingness to rely on a party in whom one has confidence (Ganesan, 1994). Inter-organizational learning is defined as the extent to which knowledge and information transferred between buyer and seller (Claro, Hagelaar and Omta, 2003). Specifically, two research questions need to be addressed: (1) How the two relational characteristics relate to innovation performance from both buyer and seller perspective? (2) Do the two types of relational characteristics complement each other? In other words, do they have interaction effects on the innovation output?

The rest of the paper is organized as follows. First, we develop our theory and research hypotheses then discuss joint problem solving as a mode to facilitate innovation performance. The determinants of joint problem solving and performance are then elaborated on based upon the relational view of supply chain management and relational exchange theory. Next, we describe our methods to test these hypotheses. Finally, results and implications are talked 
about.

\subsection{Joint Problem Solving and Buyer-Seller Innovation Performance}

Solutions to complex innovation problems require more integration and synthesis of diverse, complementary knowledge and capability (Henderson and Clark, 1990; Nickerson and Zenger, 2004; Tiwana, 2008). To acquire an innovative capability, a firm must comprehend it (Mcevily and Marcus, 2005). Previous study suggests that joint problem solving is critical to internalize capability and fostering value-enhancing inter-organizational relationships in supply chain management and relationship marketing literature (e.g., Mohr and Nevin, 1990; Mohr et al., 1996; Prahalad and Hamel, 1990). In empirical studies, researchers have typically considered joint problem solving as a facet of a broader construct, such as relational governance (e.g., Heide and Miner, 1992, Lusch and Brown, 1996). Joint problem solving is defined as the degree to which the parties to an exchange "share the responsibility for maintaining the relationship itself and for problems that arise as time goes on" (Heide and Miner, 1992). Such arrangements typically involve routines for troubleshooting problems as they arise and negotiating the mutual adaptations required to resolve the difficulty.

Joint problem-solving arrangements play a prominent role in innovative capability acquisition by promoting the transfer of complex and difficult-to-codify knowledge (Mcevily and Marcus, 2005). Through joint problem solving, relationship-specific heuristics and specialized language for conveying complex 'chunks' of tacit knowledge may be developed to reach a mutually satisfactory new solution for every contingency (Hansen, 1999). Such arrangements provide learning opportunities by creating a forum conducive to interaction and the transfer of tacit knowledge about innovative capabilities. In innovation-seeking partners, it is often initially difficult to clearly envision the intended performance outcome. For example, different firm managers might have different perspectives on what they view as the ideal solution and things may changed differently from what expected (Dougherty, 1992; Tiwana, 2008). These perspectives must be reconciled by joint problem solving arrangements to arrive at a shared conceptualization of the envisioned solution.

Therefore, although partnership provide possibilities for gaining access to complementary know-how (tacit, sticky, and noncodifiable knowledge) and technological capabilities (Kale, Singh, and Perlmutter, 2000; Mowery, Oxley, and Silverman, 1996), their coordinated utilization at the firm level is necessary to translate them into practice. By providing a forum where exchange partners can observe, experience, and demonstrate the use of a capability in practice and receive feedback, joint problem solving arrangements allow a firm to draw on the insights, experience, and ability that customer and supplier firms have to create 
forms of dealing with disagreements and other contingencies of the business relationships and in turn to be more innovative (Marshall, 2004; Dyer and Singh, 1998). The greater the extent of joint problem solving is, the greater the recognition and integration of new information about new needs and constraints that arises in progress are. We should note, however, that although joint problem solving may increase the value creation within the partnership or alliance, for individual firm, innovation performance also depends on how much of the additional value is captured by each partner (e.g., Bowman and Ambrosini, 2000; Ghosh and John, 1999). Therefore, we propose the following hypotheses:

H1a Joint problem solving will be positively related to buyer firms' innovation performance.

H1b Joint problem solving will be positively related to seller firms' innovation performance.

\subsection{Trust, Joint Problem Solving and Innovativeness}

Inter-organizational trust reflects the level of relational embeddedness and cohesiveness in buyer-seller relationships (Kale et al., 2000; Uzzi, 1997; Tiwana, 2008), which facilitates information flowing (Danny, Geoffrey and Onno, O, 2003), and enhances the efficiency of joint actions in buyer-seller relationships (Paulraj, Lado and Chen, 2008). Because the resources and information are more likely to share if a firm have confidence in the information and advice provided by an exchange partner and to believe that the recommendations made are in its own best interest (Das and Teng, 1998; Mcevily and Marcus, 2005). In addition, trust also makes it possible for a firm to be more open with its exchange partners (Dore, 1983; Ouchi, 1979). In order for transaction partners to provide information and guidance useful for solving problems and develop new products and operational process, it is necessary for the firm to reveal certain details about its operations and the challenges the partner faces. For this reason, if problems come up or market environment changes, they may share their specific knowledge to help each other jointly solve the problem and find new solutions.

Moreover, trust provides a context conducive for joint actions because the buyer and seller are less likely to discredit each other's perspectives trying to solve problems. By virtue of their reciprocal relationships, buyer and seller are also less likely to engage in cost-benefit calculus before contributing proprietary or valuable knowledge to a collaborative project (Molm, Peterson, and Takashaki, 1999). Exchange partners that trust each other are willing to make extra efforts beyond the letter of a contract in order to overcome difficulties and help each other solve problems. Therefore, such trust is a critical antecedent to joint problem solving in alliances (McEvily and Marcus, 2005), which in turn promotes innovation performance of buyer and seller as we discussed above. 
Hence, it is primarily because in such synergistic action process, information and resources are recombined, unique new solutions can be generated and relational rents can be realized (Dyer and Singh, 1998). Without joint problem solving, the latent potential of inter-organizational trust for enhancing innovation performance can not be realized. These ideas are summarized in the following hypotheses:

H2 Inter-organizational trust will be positively related to joint problem solving in buyer-seller relationship.

H3a Joint problem solving will mediate the relationship between inter-organizational trust and buyer firms' innovation performance.

H3b Joint problem solving will mediate the relationship between inter-organizational trust and seller firms' innovation performance.

\subsection{Learning, Joint Problem Solving and Innovativeness}

For joint problem solving to occur, it is necessary for the exchange partners to share information relevant to the problem. Inter-firm trust is needed but not sufficient, inter-firm learning also needed to guarantee more tacit knowledge and capability for innovative solution processed by partners and can be transferred and absorbed (Claro, Hagelaar and Omta, 2003). Inter-organizational learning is the ability to share and transfer knowledge with other partners (Lorenzoni and Lipparini, 1999). Because the information conveyed through ties that are more highly embedded is situation-specific and 'holistic,' in the sense that it consists of a composite of related details, it is both meaningful and instructive to promote joint problem-solving arrangements that allow exchange partners to engage in experimentation, observation, and search for solutions. More over, since such knowledge is difficult to codify and articulate, which makes it challenging to transfer (Zander and Kogut, 1995; Szulanski, 1996), The information shared in the learning process is often face to face, which help the exchange partners to jointly and effectively solve the common problem (McEvily and Marcus, 2005). Hence, inter-organizational learning provide new know-how, that is, new ways of doing things to jointly solve problem effectively and also provide face to face communication opportunities to jointly solve problem efficiently. Therefore, the higher the level of learning in a given buyer-seller relationship, the greater the probability of innovation is engendered from diversity of accessible knowledge, capabilities, and perspectives. Since knowledge sharing in inter-organizational learning influences innovation only if it is employed in joint problem solving to improve production and respond to customer needs, we assume that its influence on buyer and seller innovation performance is mediated by joint problem solving. Therefore, we propose the following hypotheses: 
H4 Inter-organizational learning will be positively related to joint problem solving in buyer-seller relationship.

H5a Joint problem solving will mediate the relationship between inter-organizational learning and buyer firms' innovation performance.

H5b Joint problem solving will mediate the relationship between inter-organizational learning and seller firms' innovation performance.

\subsection{Complementarities between Trust and Learning}

Complementarities are said to exist when having more of one thing increases the returns of having more of another (Milgrom and Roberts, 1995). Statistically, this represents a positive interaction effect. Viewed at firm level, it is plausible that a given partner can simultaneously be high on trust and on learning. Exchange partners that simultaneously possesses trust and learning will have access to a diverse array of specialized knowledge, perspectives, and skills and meanwhile easy to communicate and react jointly for the rising problem. Since relational capital based on mutual trust, respect, and friendship at the individual level between alliance partners created a basis for learning and know-how transfer across the exchange interface (Kale et al., 2000; Inkpen and Wang, 2006). Trust can affect both the extent of knowledge exchanged in alliances and the efficiency with which it is exchanged. A high level of trust contributes to information sharing and learning because decision makers do not feel that they have to protect themselves from the other's opportunistic behavior (Child and Faulkner, 1998). Without trust, however, the information exchanged between the partners may not be highly accurate, comprehensive, or timely because the partners are unwilling to take the risks associated with sharing information that is more valuable. Therefore, the building of partnerships will support learning. Further, the willingness of inter-firm leaning and history of successful knowledge transfer also enhance the trust between firm represented by more transparency or openness.

Therefore, we expect trust and learning ties to exhibit complementarities, i.e., a positive interaction effect on joint problem solving. However, such complementarities influence innovation only because they facilitate joint problem solving in firm level. Without joint problem solving, valued information and knowledge will not engender innovation in terms of either products or process. Therefore, we propose the following hypotheses:

H6 Inter-organizational learning complements trust in enhancing joint problem solving in buyer-seller relationship.

H7a The influence of the complementarities between inter-organizational learning and trust on buyer firms' innovation performance is mediated by joint problem solving. 
H7b The influence of the complementarities between inter-organizational learning and trust on seller firms' innovation performance is mediated by joint problem solving.

\section{Methods}

\subsection{Sample and Data Collection}

We developed a questionnaire on the basis of literature search and previous case studies (Bell, 2005; McEvily and Marcus, 2005; Hiede and Miner, 1992; Hallikas et al., 2005; Doney and Cannon, 1997). In order to test content validity of the scales, a panel with four experts was formed. We then carried out a pre-test on five suppliers in which managers and/or owners were asked to fill out the questionnaire and raise questions as problems and ambiguities arose. This information was used to further amend the questionnaires and scales. Finally, we collected data in Wenzhou area of the mainland of China from the early May 2007 to the late November 2007. We randomly selected 600 firms from a sample frame of 1000 firms compiled by the association of small and medium-sized firms (SMEs) in Wenzhou area which has the most developed SME clusters in China. Six hundreds questionnaires were sent to the firms' managers in the cities of Rui'an and Yueqing. When responding all questions about the business relationship, respondents were asked to consider their relationship with a specific partner with whom they do business regularly over the previous years. After sending a reminding message to all the potential respondents, 280 responses were returned (with a response rate of $46.7 \%$ ). Among them, 86 pieces of returned questionnaires were incompletely filled or characterized by self-evident mistakes, which were discarded as invalid ones. Hereby, the returned valid questionnaires were 194 pieces (valid response rate of $32.3 \%$ ). There were no significant differences between responding and non-responding enterprises in terms of enterprise size and age.

Table 1 provides an overview of the relative distribution of respondents in terms of the following three relevant variables: industry, sales revenues, and business characteristics.

\subsection{Measurement}

A five-point Likert response format was used (ranging from $1=$ totally disagree to $5=$ totally agree) for all items in this study to ask respondent to choose the answer that most consistent with their recognition and feelings. We measured innovation performance with three items adapted from Bell (2005). Three items were used to measure joint problem solving (McEvily and Marcus, 2005; Hiede 
Table 1 Distribution of Respondents

\begin{tabular}{|c|c|c|}
\hline & Obs. & Percentage \\
\hline \multicolumn{3}{|l|}{ Industry } \\
\hline Automobile & 32 & 16.5 \\
\hline Electric appliance & 39 & 20.1 \\
\hline Machine and equipment manufacturing & 16 & 8.2 \\
\hline Clothes and shoes & 23 & 11.9 \\
\hline Consumer products & 9 & 4.6 \\
\hline Foods & 3 & 1.5 \\
\hline Communication & 7 & 3.6 \\
\hline Service & 12 & 6.2 \\
\hline Total & 194 & 100 \\
\hline \multicolumn{3}{|l|}{ Sales revenues (million yuan) } \\
\hline Less than 1 & 3 & 1.5 \\
\hline $1-5$ & 6 & 3.1 \\
\hline $5-10$ & 12 & 6.2 \\
\hline $10-30$ & 38 & 19.6 \\
\hline $30-100$ & 83 & 42.8 \\
\hline Above 100 & 52 & 26.8 \\
\hline Total & 194 & 100 \\
\hline \multicolumn{3}{|l|}{ Business Types } \\
\hline Manufacturing & 97 & 50.0 \\
\hline Manufacturing and distribution & 63 & 32.5 \\
\hline Wholesale and distribution & 16 & 8.2 \\
\hline Retailing & 7 & 3.6 \\
\hline Other services & 11 & 5.7 \\
\hline Total & 194 & 100 \\
\hline
\end{tabular}

and Miner, 1992). They indicate the behavior of the relationships that captures the degree of joint solutions to problems a supplier demonstrates toward the selected buyer (Heide and Miner, 1992; Lusch and Brown, 1996); trust comprises multi aspects including ability, benevolence, and integrity (Mayer et al. 1995). Based on these viewpoints, we employed Doney and Cannon's (1997) scale to asses trust in buyer-seller relationships. Following McEvily and Marcus (2005) and Hallikas et al.'s method (2005), inter-organizational learning was measured with three items that reflect the extent to which interaction between buyers and sellers in knowledge sharing and integration.

Harman's one-factor test was used to check for the presence of common 
method variance (Podsakoff and Organ, 1986). We subjected all the key measures to a factor analysis and then determined the number of factors accounting for the variance in the measures. The first factor explained only $35.8 \%$ of the total variance in the data. Since a single factor did not emerge and the first factor did not account for most of the variance, we concluded that common method variance might not exist. We also assessed the reliability of the multi-item scales with Cronbach's alpha. As can be seen, all scales had reliabilities above the 0.70 threshold (Crobanch, 1951; Nunanlly, 1978).

Prior to testing the hypotheses, we conducted a confirmatory factor analysis to estimate the measurement model and to further establish uni-dimensionality and construct validity, which included all variable factors. The ratio of listwise sample size to estimated parameters of the measurement model was 11:1, exceeding the threshold level of 5:1 (Hair, Anderson, Tatham and Black, 1998). As shown in Table 2, all factor loadings were significant. The values for CFA model fit indices including goodness of fit (0.91), normed fit index (0.94), non-normed fit index (0.96), root mean square error of approximation (0.064), normed $\chi^{2}(142.64)$ and $d f(80)$. All these values indicate that the data fits the model well and hence establish the uni-dimensionality. Carr and Pearson (1999) suggested that to test convergent validity, $t$-values of the standardized coefficients between each item and variables should be above 2 (i.e., $t>2$ ) and Squared Multiple Correlations for Variables should be above 30\% (i.e., $R^{2}>0.3$ ). Accordingly, we dropped items with $R^{2}$ value below 0.3 (which was marked with * on the top right corner). The standardized coefficients and t-values for the individual paths show that all the indicators are significantly related to their underlying theoretical constructs, exhibiting sound convergent validity. The results of this analysis are provided in Table 2. Table 3 presents the means, standard deviations, correlations, and reliability coefficients (Cronbach's alpha) of the variables examined in this study.

We controlled for the following variables. First, industry refers to the industries sampled firms belongs to, including automobile, electric appliance, machine and equipment manufacturing, clothes and shoes, consumer products, foods, communication, and service industry. Second, business type refers to the main business a sampled firm is engaged into to distinguish the position of the firm in the supply chain, including manufacture, manufacture and distribution, wholesale and distribution, retailing, and other services. Third, firm size refers to the natural log of the number of full-time employees a sampled firm employs. Fourth, previous research suggests that the R\&D expenditure and innovation performance might vary with sale revenues and total assets in the sampled firms, which were added to the framework. Finally, because the sampled firms were from different areas, their cultural background and management teams' education level may vary, we coded the sampled firms according to the specific district they 
were from.

Table 2 Items and Confirmative Factor Analysis Results

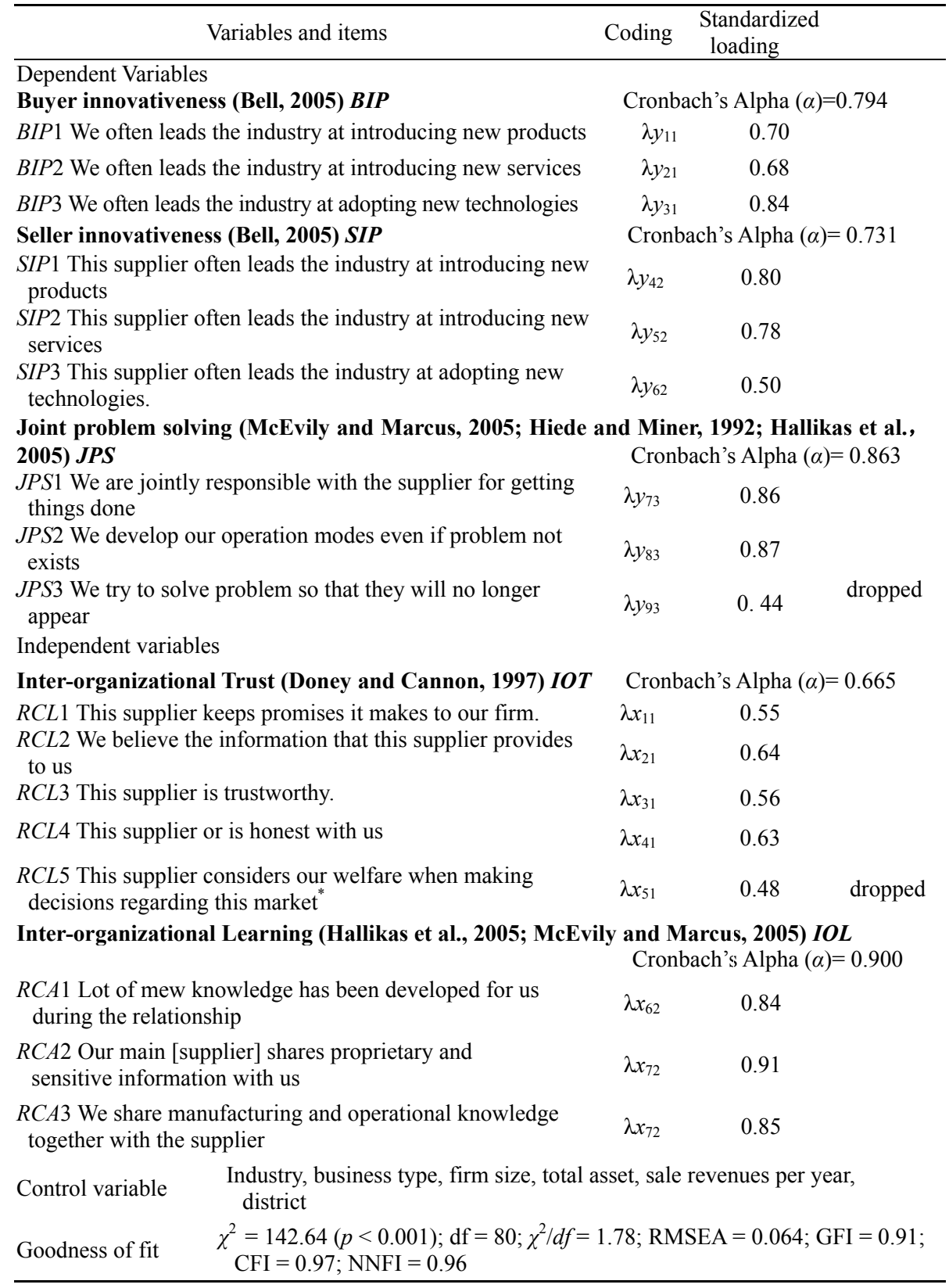

Note: All $t$-values are significant at $p<0.05$ level. 


\section{Results}

Three stepwise regression models were used to test the hypotheses. Specifically, the first one used buyer innovativeness as the dependent variable (Model 1), the second one used seller innovativeness as the dependent variable (Model 2) and with the third one used joint problem solving as the dependent variable (Model 3 ). The results of the analyses are presented in Table 4 (with the standardized regression coefficients related to the hypothesis tests italicized).

To test H1a and H1b, which proposed a positive relationship between joint problem solving and buyer innovativeness, we used a stepwise regression model in which the control variables, the predictors, the interaction term (trust $\times$ learning), and finally the mediator (joint problem solving) sequentially entered in the model. The results are summarized as Model 1. In Table 4, joint problem solving has a significant and positive relationship with buyer innovativeness $(\beta=$ $0.185 ; p<0.05)$, supporting H1a. The $R^{2}$ value increase attributable to adding joint problem solving to the model is statistically significant at the 5 percent level $(\Delta F=5.27, p<0.05)$, thereby suggesting the predictive relevance of joint problem solving to the model. Two other patterns are noteworthy in Model 1: (a) the direct effects of the predictors on the dependent variable remain significant across all model steps and (b) the direct effects of interaction term on the dependent variable remain non-significant.

Similarly with Model 1 , to test H1b, we entered the control variables, the predictors, the interaction term (trust $\times$ learning), and the mediator (joint problem solving) accordingly into the Model 2. Joint problem solving has a significant and positive relationship with seller innovativeness $(\beta=0.160 ; p<0.05)$, supporting H1b. In addition, the direct effects of the predictors on the dependent variable also remain significant across all model steps and the direct effects of interaction term on the dependent variable remain non-significant.

Model 3 is used to test $\mathrm{H} 2, \mathrm{H} 3, \mathrm{H} 4$ and $\mathrm{H} 5$, in which using the independent variables predict joint problem solving (the mediator). $\mathrm{H} 3$ predicts a positive relationship between trust and innovation performance that is mediated by joint problem solving. As Step 1 in Model 3 shows, the relationship between trust and joint problem solving is positive and significant $(\beta=0.241 ; p<0.001)$, which supports H2. The relationship between joint problem solving and buyer/seller innovativeness is also positive and significant (Model 1, Step 2). Furthermore, the direct effect decreased from trust to buyer/seller innovativeness $\left(\beta_{\text {buyer }}=\right.$ $\left.0.155 ; p<0.1 ; \beta_{\text {seller }}=0.398 ; p<0.001\right)$ when considering the mediator, suggesting that the relationship is partially mediated. This result supports $\mathrm{H} 3 \mathrm{a}$ and $3 \mathrm{~b}$. $\mathrm{H} 4$ predicts a positive relationship between learning and joint problem solving, which is also supported $(\beta=-0.412 ; p<0.001)$. The results also support 
the mediating relationship through joint problem solving proposed in $\mathrm{H} 5 \mathrm{a}$ and H5b (see Table 4).

H6 proposes that trust and learning ties in buyer and seller relationship complement each other in enhancing innovativeness, i.e., trust and learning exhibit positive interaction effects. We therefore first created an interaction term (trust $\times$ learning). We used Lance's (1988) residual-centering technique to overcome distortion of the main effects due to the tendency of main effects and interaction terms to be highly correlated. This interaction term was added to Model 3 in Step 2 to test H5. The interaction term has a positive and significant relationship with joint problem solving $(\beta=0.122 ; p<0.05)$, and its addition to the model led to a statistically significant $(p<0.05)$ increase in explained variance, supporting H6. Furthermore, the relationship between the interaction term and the mediator is positive and significant as just discussed and the relationship between the mediator and innovation performance is also proved to be positive and significant $(\beta=0.709 ; t$-value $=6.32 ; p<0.001)$ as previously described. In addition, the direct effect from the interaction term (Step 3, Model

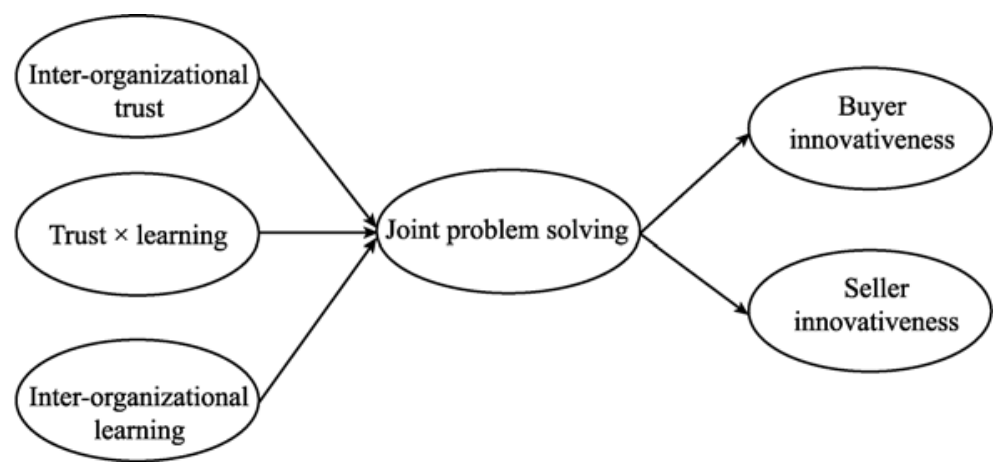

Fig. 1 Research Model

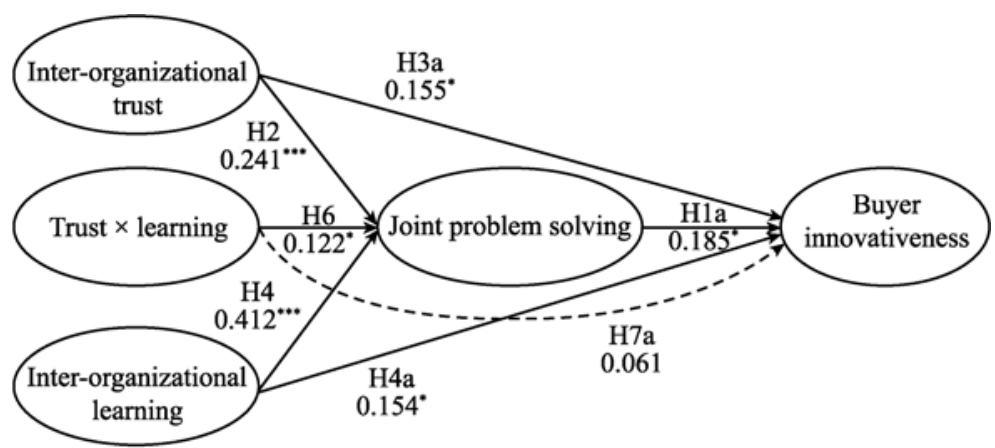

Fig. 2 Summary of Results for Buyer Innovation performance Note: *indicates significant at 0.05 level, $* * *$ indicates significant at 0.001 level (two-tailed). 
1 and model 2) is non-significant. This result suggests that the influence of the interaction between trust and learning on the dependent variable (both buyer innovativeness and seller innovativeness) is fully mediated by joint problem solving, supporting H7a and H7b, as depicted in Fig. 1 and Fig. 2.

\section{Discussion and Conclusion}

The objective of this study is to examine the tensions and complementarities between inter-firm trust and learning, as well as their effects on innovativeness in buyer-seller relationships. We assume joint problem solving as a central explanatory mechanism, through which inter-firm trust and learning influence innovativeness at the firm level directly and interactively. The findings reveal that both inter-firm trust and learning are positively and significantly related to joint problem solving, as hypothesized. Meanwhile, their influence on innovativeness is partially mediated by joint problem solving. Further, evidence strongly supports the idea that trust complement learning and that their interaction term's influence on innovativeness is fully mediated by joint problem solving.

\subsection{Theoretical Implication}

The present study makes several important theoretical implications for the research stream of supply chain management, strategic alliances, and strategy management.

Firstly, this paper builds on previous work by explicitly examining the underlying mechanisms that facilitate the acquisition of innovative capabilities from external sources. The results show that joint problem solving partially mediates the influence of trust and learning and fully mediates the complementarities effect on innovativeness. A significant mediating role of joint problem solving illustrates that external ties facilitate integration of specialized knowledge from collaborating alliance partners at firm level, which in turn influences the successful realization of innovation. These findings are consistent with the findings of Tiwana (2008) at the project level. The joint problem solving perspective therefore offers a theoretical explanation for how characteristics and contents of inter-firm relationships influence innovativeness.

Second, although a majority of previous study has documented the benefits of inter-firm information sharing and collaboration on innovativeness from buyer firms perspective (e.g., Lamming, 1993), little has specifically focused on supplier firm performance (Carter and Miller, 1989; Kotabe et al., 2003; Paulraj et al., 2008). Thus, we investigate the effects of relational resources on both buyer firms' and supplier firms' performance. We find that joint problem solving 
benefits firm's innovativeness for both buyers and sellers.

Third, another contribution of this research is that it reveals the heterogeneous influence of different features of embedded ties on the acquisition of innovative capabilities. Inter-firm collaborative linkages are associated with two distinct kinds of network benefits. First, they can provide the benefit of resource sharing, allowing firms to combine knowledge, skills, and physical assets together. Second, collaborative linkages can provide access to knowledge spillovers, serving as information conduits through which news of technical breakthroughs, new insights to problems, or failed approaches travels from one firm to another. As for the role of learning and trust, on the one hand, the successful accomplishment of novel solution requires the knowledge-spillover benefits provided by learning, on the other hand, collaboratively joint problem solving with resource-sharing requires high level of trust. It may be described as the tension between "the idea problem" versus "the action problem" (Obstfeld, 2005). Therefore, a high buyer-seller relationship on both trust and learning may be described as an ideal configuration (Tiwana, 2008).

\subsection{Managerial Implication}

The two issues raised above have important practical implications for modeling the impact of tie characteristics on organizational outcomes.

First, the relative value of trust versus leaning is likely to depend on the degree to which the benefits provided by trust and learning. To the extent that inter-firm trust and learning provide different types or amounts of benefits, the possibility of substitution between "trust" and "learning" may be limited. It is important for managers to distinguish between know-how (provide by leaning) and information (provided by trust) (Kogut and Zander, 1992). Know-how entails accumulated skills and expertise in some activities and is likely to include a significant tacit or noncodifiable dimension. Information refers primarily to facts that can be transmitted through simple communication in relatively complete form and without loss of integrity (Kogut and Zander, 1992; Szulanski, 1996). The knowledge-spillover benefits relate primarily to the transfer and sharing of know-how and physical assets, while the resource-sharing benefits of collaboration are likely to involve predominantly information. Thus, examining the content and relative contribution of inter-firm ties may help managers to design effective and efficient networks.

Second, joint problem solving plays a critical role in realizing the beneficial impact of relational recourses engender by inter-firm ties on firm innovativeness. In this study, joint problem-solving arrangement is the more prominent driver of innovative capability acquisition and acts as a key linking mechanism between ties features and the acquisition of innovative capabilities. 
Especially, two-way repeated interaction over time based on trust is very important for transferring the tacit knowledge underlying an innovative capability since the recipient rarely assimilates the knowledge completely in a single interaction, but requires multiple interactions. For this reason, establishing an effective joint problem solving mechanism can be considered a relatively immobile resource that is difficult to acquire quickly, which represent a network resource that is somewhat inimitable and sustainable source of competitive advantage.

\subsection{Limitation and Future Research Direction}

This study has several limitations, which, in a sense, represent directions for future research. First, the use of self-report data may pose such potential problems as limited recall of the respondents, biased perceptions of past realities, and common method issues. However, although our post hoc examination and validation analysis indicates no serious common method problems, future study should try to collect data from different parties (e.g., supplier or customer) to investigate the antecedents and outcomes of joint problem solving from multiple viewpoints. Since suppliers also play significant roles in affecting the quality of the supplier-buyer dyad, there is a need to examine the exchange relationship from the supplier's perspective as well. Second, we assessed only tie characteristic from learning and trust, the central and important factors in inter-firm relationship. However, these two factors might not be perfect proxies for tie features. Future work needs to attempt to add other variables that may influence joint problem solving arrangement like commitment, interdependency to the model, etc.

Acknowledgements This work is supported by the China Nature Science Foundation (No. 70772088) and China Social Science Foundation (No. 08BJY078).

\section{References}

Ahuja G (2000). Collaboration networks, structural holes, and innovation: A longitudinal study. Administrative Science Quarterly, 45(3): 425-455

Bell G G (2005). Clusters, networks and firm innovativeness. Strategic Management Journal, 26(3): 287-295

Bowman C, Ambrosini V (2000). Value creation versus value capture: Towards a coherent definition of value in strategy. British Journal of Management, 11(1): 1-15

Carr A S, Pearson J N (1999). Strategically manage buyer-supplier relationship and performance outcome. Journal of Operations Management, 17(5): 497-519

Carter J R, Miller J G (1989). The impact of alternative vendor/buyer communication structures on the quality of purchased materials. Decision Sciences, 20(4): 759-77 
Child J, Faulkner D (1998). Strategies of Cooperation: Managing Alliances, Networks, and Joint Ventures. New York: Oxford University Press

Claro D P, Hagelaar G, Omta O (2003). The determinants of relational governance and performance: How to manage business relationships? Industrial Marketing Management, 32(8): 703-716

Das T K, Teng B S (1998). Between trust and control: Developing confidence in partner cooperation in alliances. Academy of Management Review, 23: 491-512

Doney P M, Cannon J P (1997). An examination of the nature of trust in buyer-seller relationships. Journal of Marketing, 61(2): 35-51

Dore R (1983). Goodwill and the spirit of market capitalism. British Journal of Sociology, 34(4): 459-482

Dougherty D (1992). Interpretive barriers to successful product innovation in large firms. Organization Science, 3(2): 179-202

Dyer J H, Singh H (1998). The relational view: Cooperative strategy and sources of inter-organizational competitive advantage. Academy of Management Review, 23(4): $660-679$

Ganesan S (1994). Determinants of long-term orientation in buyer-seller relationships. Journal of Marketing, 58(2): 1-19

Ghosh M, John G (1999). Strategic fit in industrial alliances: an empirical test of governance value analysis. Journal of Marketing Research, 42(3): 346-357

Granovetter M (1985). Economic action and social structure: The problem of embeddedness. American Journal of Sociology, 91(3): 481-510

Gulati R (1999). Network location and learning: The influence of network resources and firm capabilities on alliance formation. Strategic Management Journal, 20(5): 397-420

Hair J F, Anderson R E, Tatham R L, Black W C (1998). Multivariate Data Analysis with Readings. Englewood Cliffs, NJ: Prentice Hall

Hallikas J, Puumalainen K, Vesterinen T, Virolainen V (2005). Risk-based classification of supplier relationships. Journal of Purchasing and Supply Management, 11(2/3): 72-82

Hansen M (1999). The search-transfer problem: The role of weak ties in sharing knowledge across organizational subunits. Administrative Science Quarterly, 44: 83-111

Heide J B, Miner A S (1992). The shadow of the future: Effects of anticipated and frequency of contract on buyer-seller cooperation. Academy of Management Journal, 35(2): 265-291

Henderson R, Clark K (1990). Architectural innovation: The reconfiguration of existing product technologies and the failure of established firms. Administrative Science Quarterly, 35(1): 9-30

Inkpen A C, Wang Q (2006). An examination of collaboration and knowledge transfer: China-Singapore Suzhou industrial park. Journal of Management Studies, 43(4): 779-810

Jarilli C J (1988). On strategic networks. Strategic Management Journal, 19(1): 31-41

Kale P, Singh H, Perlmutter H (2000). Learning and protection of proprietary assets in strategic alliances: Building relational capital. Strategic Management Journal, 21(3): 217-237

Kogut B, Zander U (1992). Knowledge of the firm, combinative capabilities, and the replication of technology. Organization Science, 3: 383-397

Kotabe M, Martin X, Domoto H (2003). Gaining from vertical partnerships: Knowledge transfer, relationship duration, and supplier performance improvement in the U.S. and Japanese automotive industries. Strategic Management Journal, 24: 293-316

Lamming R C (1993). Beyond partnership: Strategies for innovation and lean supply. Hemel Hempstead: Prentice Hall 
Lance C (1988). Residual centering, exploratory and confirmatory moderator analysis, and decomposition of effects in path models containing interactions. Applied Psychological Measurement, 12(2): 163-175

Lorenzoni G, Lipparini A (1999). The leveraging of inter-firm relationships as a distinctive organizational capability: A longitudinal study. Strategic Management Journal, 20(4): 317-338

Lusch R F, Brown J R (1996). Interdependency, contracting, and relational behavior in market channels. Journal of Marketing, 60: 19-38

MacKinnon J G (2002). Bootstrap inference in econometrics. Canadian Journal of Economics, 35: 615-645

Marshall C (2004). The dynamic nature of innovation partnering: A longitudinal study of collaborative inter-organization relationship. European Journal of Innovation Management, 7(2): $128-140$

Mayer R C, Davis J H, Schoorman F D (1995). An integration model of organizational trust. Academy of Management Review, 20(3): 709-734.

McEvily B, Marcus A (2005). Embedded ties and the acquisition of competitive capabilities. Strategic Management Journal, 26: 1033-1055

Milgrom P, Roberts J (1995). Complementarities and fit: Strategy, structure, and organizational change in manufacturing. Journal of Accounting and Economics, 19(2/3): 179-208.

Mohr J, Nevin J R (1990). Communication strategies in marketing channels: A theoretical perspective. Journal of Marketing, 54(4): 36-51

Mohr J, Spekman R (1994). Characteristics of partnership success: Partnership attributes, communication behavior, and conflict resolution techniques. Strategic Management Journal, 15: $135-152$

Molm L, Peterson G, Takashaki N (1999). Power in negotiated and reciprocal exchange. American Sociological Review, 64(6): 876-890

Mowery D, Oxley J E, Silverman B S (1996). Strategic alliances and inter-firm knowledge transfer. Strategic Management Journal, 17: 77-91

Nickerson J A, Zenger T R (2004). A knowledge-based theory of the firm-the problem-solving perspective. Organization Science, 15(6): 617-632

Obstfeld D (2005). Social networks, the tertius lungens orientation, and involvement in innovation. Administrative Science Quarterly, 50(1): 100-130

Ouchi W G (1979). A conceptual framework for the design of organizational control mechanisms. Management Science, 25: 833-848

Paulraj A, Lado A A, Chen I J (2008). Inter-organizational communication as a relational competency: Antecedents and performance outcomes in collaborative buyer-supplier relationships. Journal of Operations Management, 26: 45-64

Podolny J M, Stuart T E (1995). A role-based ecology of technological change. American Journal of Sociology, 100(5): 1224-1260

Podsakoff P, Organ D (1986). Self-reports in organizational research: Problems and prospects. Journal of Management, 12(12): 531-544

Powell W W, Koput K W, Smith-Doerr L (1996). Inter-organizational collaboration and the locus of innovation: Networks of learning in biotechnology. Administrative Science Quarterly, 41: 116-145

Prahalad C K, Hamel G (1990). The core competence of the corporation. Harvard Business Review, 68(3): 79-91

Ragatz G L, Handfield R B, Scannel T V (1997). Success factors for integrating suppliers into new product development. Journal of Product Innovation Management, 14: 190-202 
Shane S, Cable D (2002). Network ties, reputation, and the financing of new ventures. Management Science, 48(3): 364-381

Stuart T (1998). Network positions and propensities to collaborate: An investigation of strategic alliance formation in a high-technology industry. Administrative Science Quarterly, 43(3): 668-698

Szulanski G (1996). Exploring internal stickiness: Impediments to the transfer of best practice within the firm. Strategic Management Journal, 17: 27-43

Teece D J (1989). Inter-organizational requirements of the innovation process. Managerial and Decision Economics, 10: 35-42

Tiwana A (2008). Do bridging ties complement strong ties? An empirical examination of alliance ambedexiterity. Strategic Management Journal, 29: 251-272

Uzzi B (1997). Social structure and competition in interfirm networks. Administrative Science Quarterly, 42: 35-67

Zander U, Kogut B (1995). Knowledge and the speed of transfer and imitation of organizational capabilities. Organization Science, 6(1): 76-92 